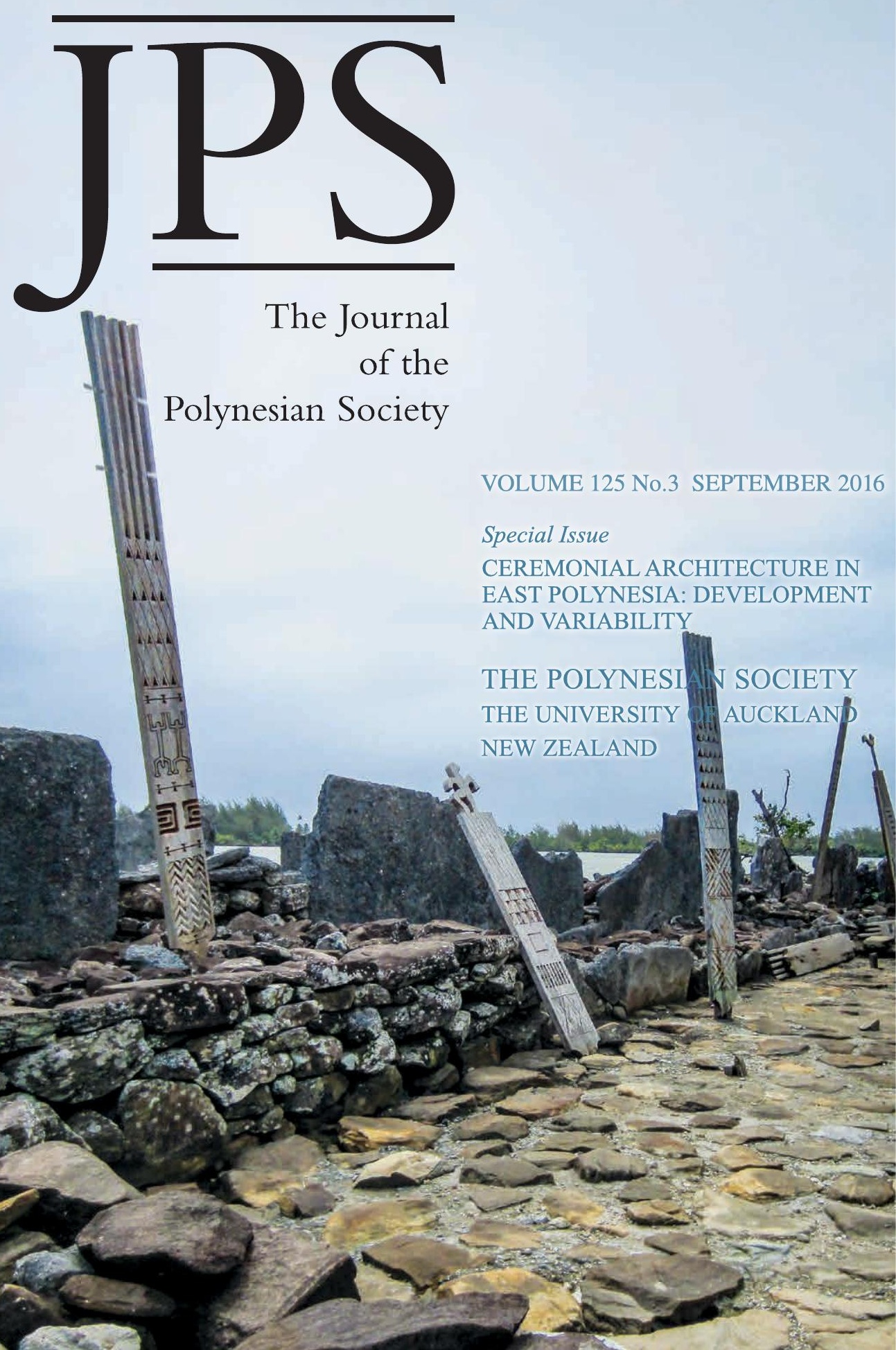




\title{
EXPLORING RELIGIOUS PRACTICES ON \\ POLYNESIAN ATOLLS: A COMPREHENSIVE \\ ARCHITECTURAL APPROACH TOWARDS THE MARAE \\ COMPLEX IN THE TUAMOTU ISLANDS
}

\author{
GUILLAUME MOLLE \\ Australian National University
}

In central East Polynesia, archaeological research on ritual architecture has developed unequally across the archipelagos. Religious structures or marae of the Society Islands have guided the interest of many authors who published largely descriptive syntheses (Gérard 1974, 1978a, 1978b) and typological analyses, including discussions about local developments of the so-called "marae complex" (Eddowes 1991, Emory 1933, Kahn and Kirch 2014, Maric 2013, Wallin 1993). In contrast, marae studies are less developed in the Austral and Marquesas Islands where ritual monuments are usually integrated with broader settlement pattern studies in which they play a minor role (see reviews in Conte 2000, Molle 2015: 7). In the Tuamotu Islands, although marae prevail in the archaeological record, comprehensive studies on ancient ritual architecture are still lacking.

The Tuamotu Archipelago is one of most extensive groups of coral islands in the Pacific and the largest in central Polynesia; it includes 78 atolls and stretches over $1800 \mathrm{~km}$ from northwest to southeast between the Society and Gambier Islands. The archipelago is traditionally divided into several subareas (Fig. 1) characterised by cultural and linguistic specificities (Stimson and Marshall 1964). Archaeologically these atolls are distinctive for their extreme ecological conditions which do not favour the preservation of archaeological remains. In addition to the lack of sedimentation, which limits the development of buried anthropic layers, the relatively high frequency of devastating cyclones also has contributed to the disappearance of ancient domestic sites which were made of perishable materials. Only marae, the sole structures built in coral stones, have stood the test of time. As a consequence, the attention of archaeologists, as well as earlier missionaries and amateurs, has mainly focused on these ceremonial places.

The earliest mentions of marae were provided by the first Catholic missionaries who settled on the islands from 1849. Fathers Audran and Montiton especially could almost be considered ethnographers given the ways that they systematically collected oral traditions about the ancient ritual practices conducted on marae; they were among the last witnesses of such practices before they were forbidden and then disappeared with the installation 


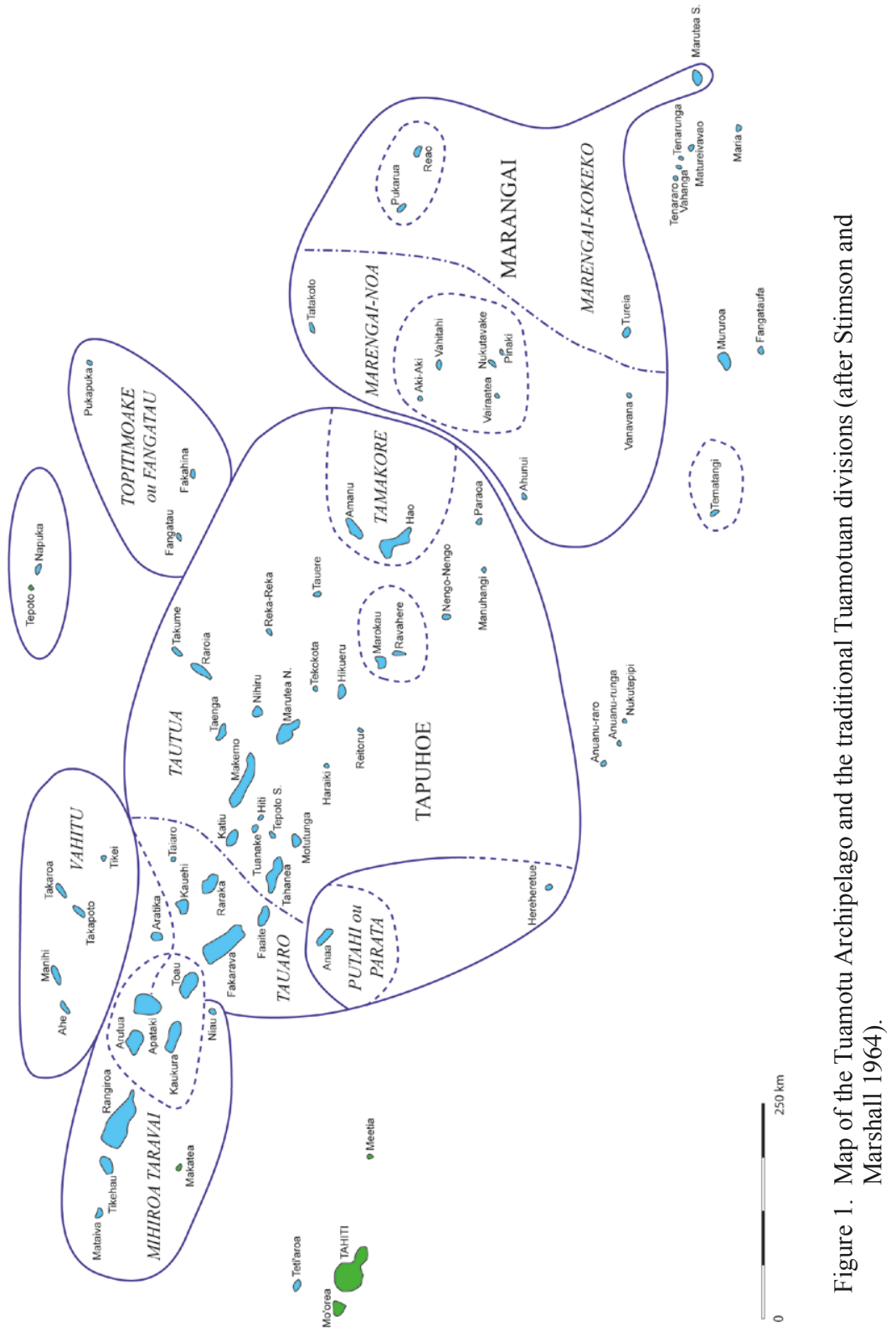


of Christianity (Audran 1918a, 1918b, 1919, 1927a, 1927b, Montiton 1874). At the turn of the 20th century, this approach of documenting religious sites was pursued by French naturalist and amateur archaeologist L.G. Seurat (1905) and historian E. Caillot (1910, 1932). Scientific archaeological excavations started in the 1930s with the Bernice P. Bishop Museum's expeditions, the first taking place in 1929-1931 in the central atolls, followed by the Mangarevan Expedition in 1934. Kenneth P. Emory was responsible for the archaeology and led the first survey of surface remains, while Frank J. Stimson was in charge of the linguistic research (Emory 1932, 1975, Stimson 1933a, 1933b, 1937, Stimson and Marshall 1964). Emory described in detail different types of marae and features on the atolls, revealing high variability in these monuments, which at the time was considered a result of both internal developments and external influences and migrations (Emory 1934, 1939, 1947, 1970).

Since the 1960s, French researchers from the Archaeology Department of the Service de la Culture et du Patrimoine in Papeete have conducted more surveys on the Tuamotuan atolls (often in the context of Cultural Resource Management or CRM archaeology), which have considerably enriched Emory's original marae database (Chazine 1977, 2003, 2005, Dauphin 2005, Jacq et al. 2011a, Jacq et al. 2011b, Marchesi and Maric 2005, Maric 2010, Maric et al. 2010, Niva 2007, Niva and Poroi 2005, Sodter 1984, Souhaile 1972, Vérin 1964, Vigneron 1984). Particularly important contributions came from Jose Garanger, who carefully excavated some sites on Rangiroa (Garanger and Lavondès 1966), and later from Eric Conte who led fieldwork at a series of sites on Napuka, Tepoto and on the central atolls (Conte, 1988, 1990, 2006). Also of importance was a multidisciplinary project initiated by S. Hatanaka on Reao that involved archaeologists (Chazine 1982, 1984, Nitta 1982, Sinoto 1976).

Both the vast amount of ethnographical and archaeological data related to marae, and the high variability of Tuamotu monuments, create a favourable context for the study of complex connections between traditional religion, ceremonial architecture and socio-political developments within a cultural and geographic entity. The analysis of marae serves as a critical avenue for understanding processes of cultural change, as well as ultimately enhancing our broader view of the Polynesian marae complex evolution. This was the purpose of Emory's initial study of Tuamotu marae development (1934), which he later came to reconsider in a wider regional perspective (Emory 1970). One must admit that at the time his model was built on non-exhaustive data sets, and included only surface recordings, and for these reasons his stylistic comparisons must be put into question. Still, this pioneer study remains an important reference, and has influenced archaeologists engaged 
in the region. While documentation has increased considerably since then, unfortunately most of it is confined to unpublished "grey" literature and thus remains unknown and difficult for non-Francophone readers to access. As a consequence, Tuamotu marae have been neglected (or even omitted) in many post-Emory studies of Polynesian ritual sites while the Society Islands, Hawaiian Islands and Easter Island have received more attention (see Cochrane 1998, 2015: 41).

For these reasons, and given the almost 70 years since Emory's major publications, it appeared necessary to reassess ritual architecture development within the Tuamotu Islands. This article presents a new classification of marae, building on a wide-scale synthesis of surface data (Molle 2015). Analysis of the geographic distribution of marae types highlights some cases of local development. Beyond the descriptive aspect, this study seeks to understand the origins of patterns of variability and the nature of local trajectories. Investigation of various factors identifies internal innovations to ritual and socio-political functions as important, as well as external influences.

\section{BUILDING A COMPREHENSIVE CLASSIFICATION OF TUAMOTU MARAE}

Information on marae and rituals in the Tuamotu Islands derives from archaeological research, oral traditions, ethnohistorical accounts and ethnographic works. The heterogeneity of sources provides various views regarding marae typologies and use. The pioneering study by Emory (1934, 1947) proposed groupings of marae based on the presence/absence of major features (Fig. 2). These included the $a h u$ (the main platform and the most tapu or sacred feature of the site), upright coral stones and cists, all organised within a sacred space (tahua) delimitated by enclosure systems of various forms. Later authors tended to develop their own typologies which can only be used on a small number of atolls. For instance, Garanger and Lavondès (1966: 63) distinguished between simple $a h u$ in a non-enclosed court and $a h u$ built in a court enclosed by double-alignments of coral slabs with coral gravel fill, the latter only being documented in the western Tuamotus. On Reao, the easternmost atoll of the group, Sinoto simply considered open courts and courts marked by ridges of coral (1976: 109), while Nitta (1982: 381) further divided his classification into 11 subclasses based on the complexity of ahu construction. Based on his survey of 10 atolls located in the centre of the archipelago, Conte (1990: 85) defined seven subclasses of marae, depending on both the number of $a h u$ and their position relative to one another. Other authors have applied those classification systems to their own discoveries. In his recent phylogenetic analysis of similarity in ritual architecture, Cochrane (2015: 29) only included Reao marae for the Tuamotu region, thereby underrepresenting marae variation in this group. 
Guillaume Pole 267

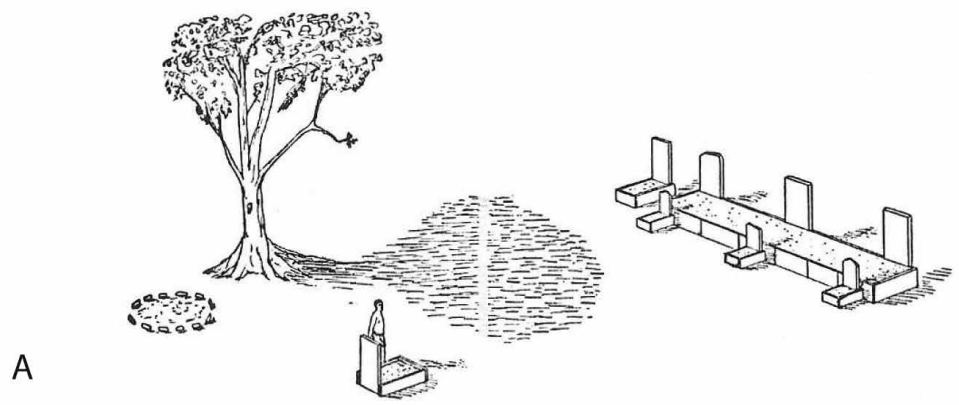

B
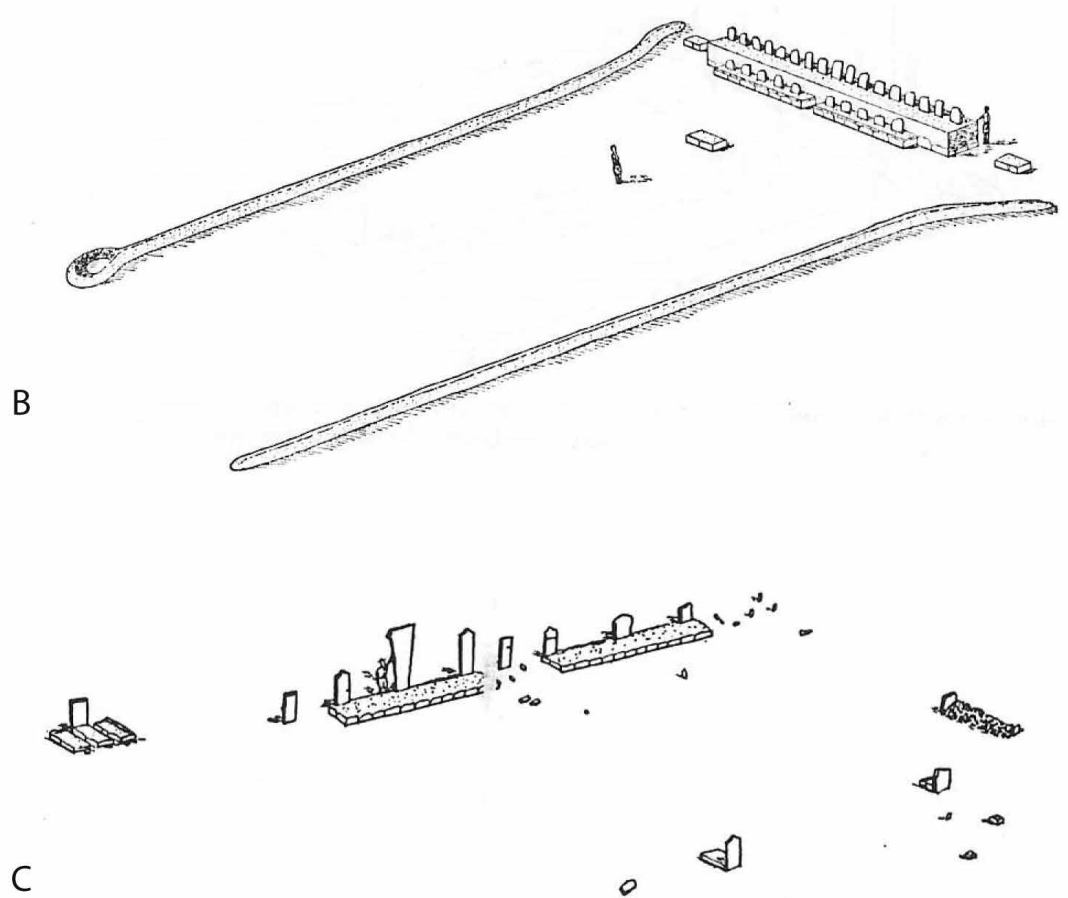

8

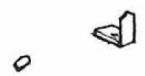

Figure 2. Mara styles as recorded by Emory (1934) corresponding to:

A. Type 2.1; B. Type 2.3 (Rear); and C. Type 3 (Fangatau) in the new typology presented in this article. 
To better address the heterogeneity issue, information about marae sites was compiled and synthesised in a relational database that integrates both archaeological and ethnographic materials (Molle 2015: 20). Of the 78 atolls, 36 islands have been surveyed archaeologically, providing site locations and sometimes marae descriptions. Additionally, the existence and locations of marae are indirectly documented on 32 other atolls through oral traditions, and accounts and records from local informants. Unfortunately, many of these sites have disappeared, either destroyed by missionaries in the 19th century, by cyclones or by the effects of time. The first systematic appraisal carried out in 2007 led to a total of 497 entries in the database. Since then, more surveys have increased the count to 650 marae. However, for classification purposes only 147 marae were considered to be sufficiently well preserved to be employed in a formal examination.

After examining the occurrence of attributes across the recorded marae, I determined that some attributes were more important than others. Table 1 lists Tuamotuan marae attributes sorted by architectural importance, from the most frequent to the most infrequent. Like elsewhere in Polynesia, the $a h u$ attribute (consisting of a low platform in the Tuamotus) appears to be the fundamental component of ceremonial sites, in front of which ritual actions were conducted. The $a h u$ also defines the general orientation of the court and influences the position of other features within the sacred space. The number of $a h u$ on Tuamotuan marae may be as many as four or when absent, as is sometimes the case, other alternative arrangements were found to maintain its symbolic purpose. Moreover, $a h u$ forms vary in dimensions and construction from simple, low platforms delimited by coral slabs set on edge and filled with coral gravel, to stepped platforms, which are sometimes made of piled-up slabs.

The enclosure system is a second attribute of importance. The presence of built walls is not systematic and most of the time the court was delimited by fences made of perishable material. When present, walls vary considerably in terms of dimensions and stonework, from double-alignment walls on Rangiroa to coral ridges on Reao. Additional attributes, including upright stones and cists, were rarely taken into consideration in previous studies. This is mainly due to the non-systematic recording of their presence, and the supposedly random patterns of spatial organisation of these attributes. As a consequence, they are considered separately. The same is true of the fourth category of attributes, which are also less frequently encountered and include pits, ovens and independent shrines. Based on religious traditions, I argue that attributes 3 and 4 likely served very specific ritual purposes and as such were not as indispensable as the $a h u$ and enclosure systems. 
Table 1. Description of marae attributes, with the architectural features organized by importance (see text for full explanation).

Attribute 1: $A h u$ Form and Number

A raised rectangular platform located at one end of the marae courtyard, which served as the most sacred focal point during rituals.

Attribute 2: Enclosure System

Features which delimited the sacred space, made of either perishable or non-perishable materials. In the latter case, they consisted of two or more courses of coral stones, which were placed along any side of the marae courtyard.

Attribute 3: Coral Slab Features

Ahu upright

Independant upright

Cist

Cist with upright
Coral slabs directly associated with the $a h u$, placed either in front or on top of the $a h u$, and signifying deities and ancestor spirits during rituals.

Coral slabs placed within the boundaries of the marae space, serving either as backrests or memorial stones.

A small rectangular enclosure limited by coral slabs set on edge, sometimes filled with coral gravel, which served as a place for depositing offerings.

A small rectangular enclosure limited by coral slabs set on edge, including a coral upright at one end, which served as a place for depositing offerings.

Attribute 4: Secondary Architectural Features

Pit

Oven

Ruahatu
A depression, often circular in shape, and sometimes delimited by coral stones, which served as a refuse pit.

A circular-shaped oven made of coral stones, usually for cooking turtles.

An accumulation of coral branches, sometimes limited by a cist-like structure made of coral slabs set on edge, which servied as a shrine dedicated to the marine deity, Ruahatu. 
Building a typology of monuments that reflects the high regional variability of sites is challenging and can be achieved in different ways. The typology presented here is not intended as an ending but rather as a tool for interpreting the meaning of marae types which are likely to reflect historical developments across the region; these ideas can be further investigated through future archaeological and ethnographic studies. For this reason, a taxonomic (hierarchical) classification was favoured over a paradigmatic classification (Adams and Adams 1991, Dunnell 1971); I argue that this approach allows more flexibility as it uses criteria of which the occurrence and value might differ across sites. Moreover, such a taxonomic classification unifies previous attempts in that it maintains the hierarchical importance of features accepted by many earlier authors, and recognises the number of $a h u$ and the nature of the enclosure system as the major criteria for distinguishing variants.

The three most conspicuous variants of attributes 1 and 2 were selected as the primary criteria for defining types and subtypes: $a h u$ number, presence/absence of enclosures, and morphology of the ahu platforms (simple versus stepped). However, they turned out to be insufficient for tackling the complex marae variability in Tuamotus. In order to encompass all archaeologically recorded patterns throughout the region, subgroupings were then further detailed through additional variations, of which the most distinctive are the types of enclosure walls. Other infrequent variations (often limited to subclasses) include: the position of $a h u$ in relation to the enclosure wall, multiple settings of $a h u$ features consisting of joint/separated platforms, number of uprights on $a h u$, and various combinations of coral slab features and secondary architectural attributes (uprights, cists, ovens etc.) within a court space.

Figure 3 offers a synthesis of the main marae types, as well as the most common variations/combinations documented in the Tuamotus and discussed in this article. Type 1 defines marae that lack a classic $a h u$ but still are described as ceremonial places and which display a combination of ritual features grouped in a non-enclosed space. Type 2 marae, with a single $a h u$, are the most common in Tuamotus, although I distinguish between Type 2.1 (without constructed walls), Type 2.2 (double-alignment walls enclosures, where two alignments of coral slabs have been set on edge and the space between filled with coral gravel) and Type 2.3 (limited on the long axes by constructed coral ridges/elongate mounds). Notably within this latter subclass, there is considerable variation in the $a h u$ structures, although they are consistently made of piled-up coral slabs. Preliminary surface interpretation of some sites has led to further subdivisions of marae with two $a h u$ (Type 3) or three or four $a h u$ (Type 4) apparently grouped in an open court space. Finally, Type 5 includes a series of sites that do not display the 
Guillaume Molle 271

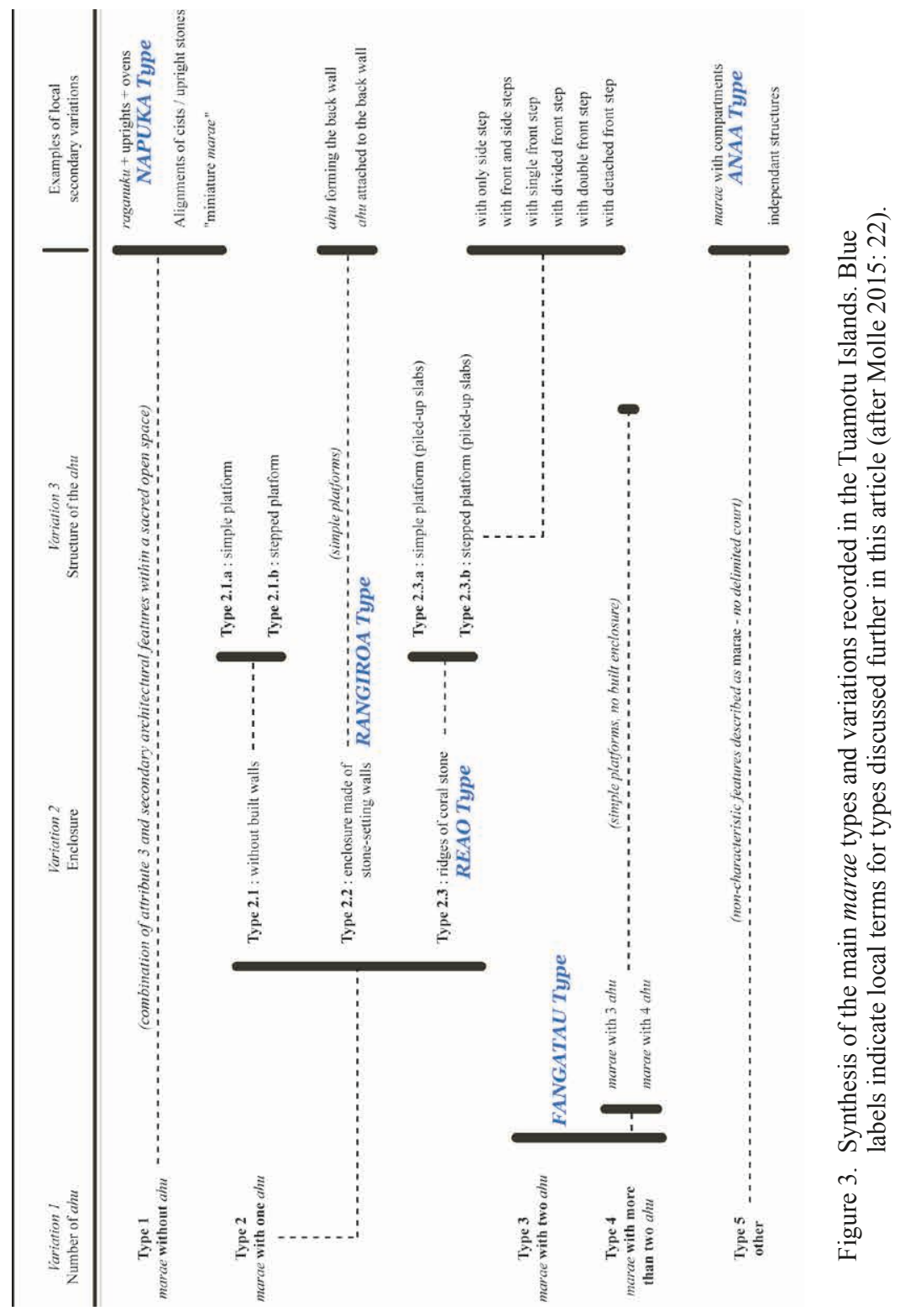


usual characteristics of marae. However, as they are traditionally designated as such by local inhabitants and traditions, they must be taken into account in this comprehensive analysis. The typology, although it might appear less objective than a paradigmatic approach, better serves the purpose of understanding the geographic distribution and development of marae types.

\section{GEOGRAPHIC DISTRIBUTION OF MARAE TYPES}

Building on Stimson and Marshall's (1964) traditional view of sub-regional divisions (see Fig. 1), a geographic distribution analysis of marae types was conducted at the archipelago scale. Table 2 shows the distribution of 147 classified marae across 12 Tuamotu areas (Molle 2015: 65-69). Figure 4 displays the results of a Correspondence Factor Analysis where the goal is to assess the attraction/repulsion between data in a matrix and to represent these phenomena on a cloud-dot graph where the two axes represent the factorial dimensions (see Benzécri 1973 for details of this method). In the present case, the analysis was run on the Table 2 data. The results demonstrate the occurrence of marae types within certain geographic divisions, confirming some patterns of local variability previously proposed by Emory $(1934,1947)$ and Garanger and Lavondès (1966). Type 2.1, displaying a simple combination of a single $a h u$ within an open court, is the most common subclass and is present in all areas, although it is particularly well documented in Marangai and Vahitu. Type 2.2, with double-alignment walled enclosures, is exclusively present in the westernmost region, the most frequent occurrence being on Rangiroa Atoll, which led us to refer to it as the "Rangiroa type" (see Fig. 3). The third subclass (Type 2.3), characterised by both ridges of coral and ahu made of piled-up stones, is limited to the Reao area and is defined as such. On Napuka and Tepoto, some marae without $a h u$ display a recurring combination of features that are designated as an original variation of Type 1. Types 3 and 4 correspond to marae with two or more $a h u$. Those are documented in several atolls of the central region, although the strongest association occurs in the Fangatau area, which may indicate another example of local innovation. Finally, although it does not appear clearly on Figure 4, due to the lack of information by the time of the analysis, recent work on Ana'a Atoll (Parata area) has shown that a marae made of a series of small compartments is actually a unique variation of the Type 5 marae (Maric et al. 2010).

\section{INVESTIGATING CULTURAL CHANGES THROUGH MARAE VARIABILITY}

The development of Polynesian ritual architecture has long been analysed through the perspective of similarity patterns and notions that similarity indicates relative cultural homogeneity across the Polynesian triangle (Emory 1933, Linton 1925). These similarities are now largely accepted 
Guillaume Molle 273

\begin{tabular}{|c|c|c|c|c|c|c|c|c|c|c|c|c|c|}
\hline సే & $=$ & $\stackrel{m}{-}$ & 0 & \pm & $n$ & - & $\infty$ & શે & 6 & $\infty$ & $n$ & F & Ð \\
\hline 怘 & - & 0 & 0 & $N$ & 0 & 0 & 0 & 0 & 0 & 0 & 0 & $\sim$ & $n$ \\
\hline 离 & - & - & 0 & 0 & 0 & 0 & 0 & $\nabla$ & 0 & - & 0 & 0 & $r$ \\
\hline 芯 & 0 & 0 & 0 & $m$ & N & 0 & 0 & $\infty$ & - & 0 & - & $n$ & હ \\
\hline 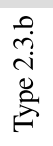 & 0 & 0 & 0 & 0 & - & 0 & 0 & 0 & 0 & 0 & 0 & $\stackrel{\varrho}{ }$ & $=$ \\
\hline 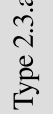 & 0 & 0 & 0 & 0 & 0 & - & 0 & 0 & 0 & 0 & 0 & $\Xi$ & 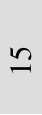 \\
\hline 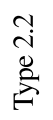 & $n$ & - & 0 & 0 & 0 & 0 & 0 & 0 & 0 & 0 & 0 & 0 & ט \\
\hline 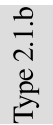 & 0 & - & 0 & 0 & 0 & 0 & 0 & 0 & 0 & 0 & 0 & - & $N$ \\
\hline 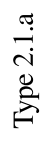 & $\forall$ & 으 & 0 & 6 & 0 & 0 & $N$ & $r$ & $n$ & $r$ & - & I & $\dot{\sim}$ \\
\hline 芯 & 0 & 0 & 0 & $m$ & $N$ & 0 & 6 & 0 & 0 & 0 & $m$ & $m$ & I \\
\hline & 苞 & 禀 & 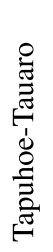 & 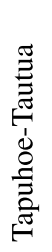 & 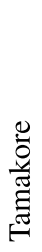 & 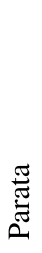 & $\begin{array}{l}\frac{\widetilde{r}}{\vec{Z}} \\
\text { 胥 } \\
\text { Z }\end{array}$ & 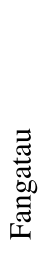 & 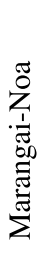 & 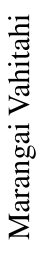 & 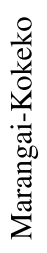 & $\underset{\mathscr{U}}{\mathscr{\mathscr { U }}}$ & స్తేర \\
\hline
\end{tabular}




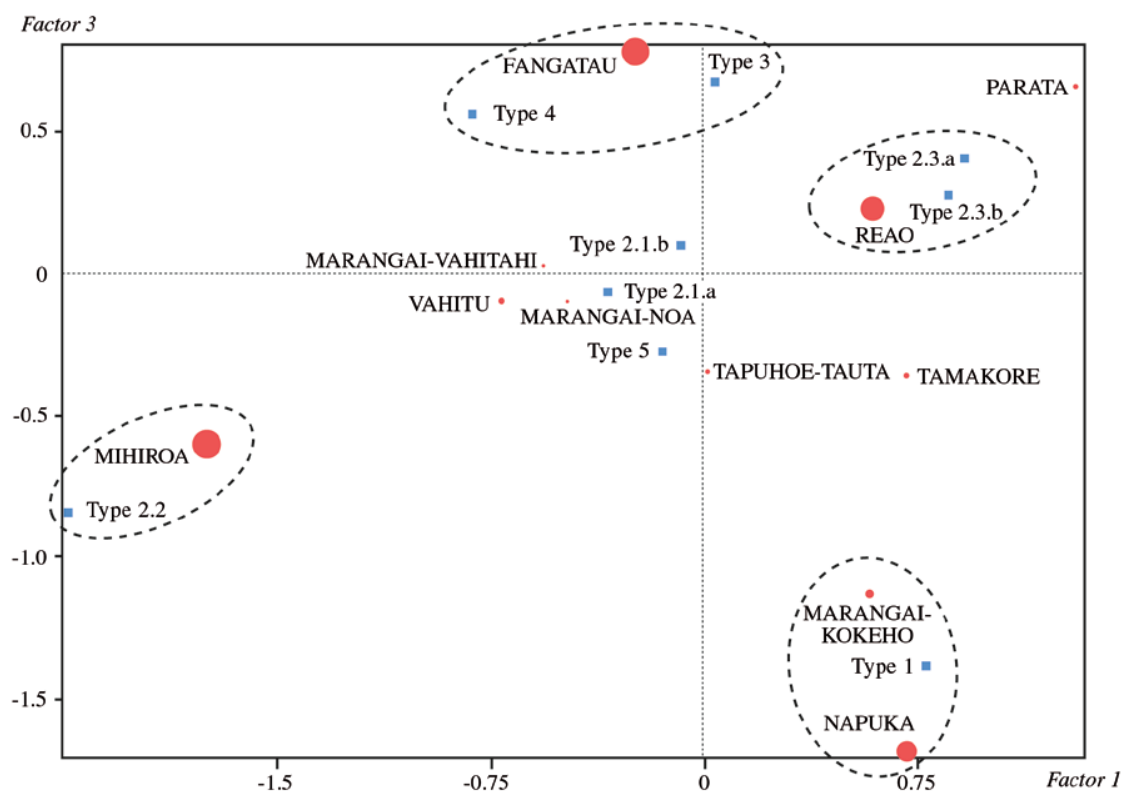

Figure 4. Geometric representation of the Correspondence Factor Analysis showing the relative distribution of marae types (square) within geographic divisions (dots). Clusters (dotted lines) highlight specific associations. The size of the dots refers to the weight of each division in the analysis (after Molle 2015).

as a product of phylogenetic relationships that reflect a common ancestry of Polynesian cultures (Cochrane 2015, Kirch and Green 1987, 2001). The original features associated with the earliest conception of marae in Western Polynesia were introduced to the central region by the first migrants and spread out across the archipelagos during the following period of inter-island contacts. However, groups adopted and developed various combinations of these initial features at regional and local scales that led, over time, to the large variability of religious monuments noted by the first Western explorers from the 17th century. Regarding the religious and socio-political importance of marae in the traditional cultural landscape, this variability likely reflects long-term processes of transformations (Conte 2000: 201, Eddowes 1991). Breaking with previous research focusing on the degree 
of cultural relatedness (e.g., Cochrane 2015), I choose here to fully explore variability in Tuamotu marae in order to reconstruct the widest array of processes of cultural change within this Polynesian region.

This approach calls for identifying the various factors that drove the innovations in ceremonial architecture which are revealed in the classification. Factors of differentiation have been proposed by authors interested in the broader issue of Polynesian culture changes (see Conte 1997, Kirch 1984). Among them is the "founder effect", whereby only a part of the original parent stock makes up the new founding population which enables later differences. Adaptive capacity to environmental constraints has also been used to explain the recasting of practices. Here I argue for the notion of socio-ritual adaptation by which specific forms of architecture may have developed internally in response to particular spiritual or socio-political needs. Finally, the isolation of islands is a recurring argument to explain differentiation in the Polynesian region. However, communities on Tuamotuan atolls maintained relationships with neighbouring archipelagos, especially the Society Islands and probably with the Gambier Islands as well (Torrente 2012). As such, we must consider in our analysis the possibility of external influences on marae development that might have led to either similarity in patterns or reformulation and the emergence of hybrid forms of architecture.

\section{ENDOGENOUS FACTORS AND SPECIALISED ARCHITECTURE}

\section{Socio-Political Organisation and Marae Networks}

In central East Polynesia, the marae establishes the rights and relations between social entities acting at different levels (individuals, families, lineages, chiefdoms). In the Tuamotus, social organisation was based on a group affiliation called gati. It was itself composed of branches, also called gati, which gathered people who descended from a common ancestor. According to the prevalent rule of primogeniture, the chief derived from the branch which was genealogically the closest to the ancestor, and was designated as gati ariki (see Nolet 2014, Torrente 2012). Each gati benefited from an extended autonomy and formed a religious and political community (matakeinanga) independently settled on a portion of the atoll. The material property of a gati included a marae, a meeting place (tahua), water sources or wells (vai), fishponds ('aua i'a), tracks ('e'a), horticulture pits (maite), long houses used for meetings (fare roa) and burial places (Nolet 2007). In this view, marae marked the establishment and the control of a land and as such symbolised the unity of the group as a whole. For this reason, gati marae were the most important sites and ones where communal ceremonies were performed on various occasions. Within the large gati, lineages and families 
possessed their own marae which were dedicated to domestic and private ritual practices, about which the literature remains largely silent. The hierarchy of marae thus reflected the social organisation of the ancient communities. However, it is important to understand that the hierarchy also expressed itself in the architectural forms of marae. Settlement patterns studies in Polynesia often relate the size and the complexity of a site to the rank of its owner, as based on economical (labour capacity) and symbolical (concentration of mana according to prestige of an individual) considerations (Conte 2000: 184, Orliac 2000: 99). This determinist view echoes the situation in the Society Islands according to the traditional classification of marae by Rev. Orsmond (Gérard 1978a: 66, Henry 2000). Such criteria must be considered cautiously in Tuamotus, especially regarding the high degree of variability across the region. No direct and constant correlation between the size of sites and status can be proven in the current state of our knowledge.

Marae are also indicators of relationships between gati. In the same way that groups descend from ancestors or heroes, marae supposedly follow a line of descent from the original marae founded in a newly discovered land, usually referred to as marae tumu. Such a marae is known on Rangiroa, the Ra'ipu Marae, which would have been founded by Oio, first chief of the atoll (Ottino 1965: 25). Affiliations are often indicated when founding a new marae through the use of a symbolic stone from the marae tumu; through this a part of the mana is thus transmitted to its descendant (Henry 2000: 149). It is of course difficult to demonstrate such practices archaeologically, although Garanger discovered an exogenous basalt stone in the court of Tivaru Marae on Rangiroa, indicating a potential relation with the nearby Tahiti Peninsula (Garanger and Lavondès 1966). On the other hand, affiliations between gati can be assessed through the sharing of marae names. Emory was the first to consider these relationships by assuming that the original name of the marae tumu was transmitted to its descendants (Emory 1934: 15-16). Building on his idea, I identified 27 names shared by 79 marae sites (Molle 2015: 52) and showed the existence of marae networks stretching over the entire archipelago. ${ }^{1}$ The most important was certainly the Aturona network that originates from a marae tumu on Fangatau, which belonged to the Chief Varoa. A traditional hero's journey recounts that his son, Mapu-teretere, travelled through the atolls, establishing alliances and kinships with other groups by founding new marae bearing the name of Aturona (Torrente 2012: 285). Unfortunately, our archaeological perspective on a potential "monumental reproduction" along the descent line of marae remains limited, as most of the sites have been destroyed and cannot be classified. 


\section{Ritual Practices}

Aside from their function as socio-political markers, marae were foremost places where a series of rituals took place in order to ask favours of the gods and ancestors. Tuamotuan traditions and ethnographic records give evidence of various ceremonies intended for the renewal of fertility, propitiatory rites, asking for protection and revitalisation of collective memory. Aside from these collective practices, rituals also occurred at a private level, including the first pregnancy of a woman, the birth of the first child and the burial of placenta, the rite of incision of the prepuce for young men, ear-piercing for girls, treatments of diseases etc. (Emory 1947: 58). Archaeologically, it is useful to consider the degree of ritual specialisation of the sites, and to possibly relate specific ritual functions to certain types of architecture.

Among the many marine species that were the object of rituals on marae, green sea turtles (Chelonia mydas) were essential in the Tuamotuan culture and religion (Nolet 2000). The capture and ritual consumption of the first turtle (mahuta) marked the beginning of the season of abundance and was seen as a gift from the ancestors to the living (Conte 1988 [II]: 8). Consumption of turtle meat was traditionally a collective activity among gati and family groups, and took place on marae during long and complex ceremonies that continued until the second half of the 20th century; these were described in details by missionaries on Napuka, especially Montiton (1874; see also Emory 1947: 59). It is said that the participants, including the chief and elders, sat first in the left court of the marae, an area called the te fanui. Then small wooden boxes (fare tini atua) containing relics of the ancestors (Kaeppler 2007) were placed on a structure (raganuku) which on some Napuka marae (Type 1) replaced the $a h u$. It was made of wooden planks that were placed on top of low coral slabs (Molle 2015: 33). The cooking of the animal took place at two different times and in separate ovens which were located in the rear of the court. The chief and his assistant benefited from the first piece of meat, after which those remaining were distributed among the other men, who then moved to the right court called te tohitika. No specific feature has been described for this latter court space which, as a simple meeting area, is difficult to identify archaeologically. The extreme specialisation of theseType 1 Napuka marae is confirmed by their designation as marae tifai 'marae for turtles' (Conte 1988 [II]: 12). In the Napuka-Tepoto area, there is no doubt that the large marae Rangihoa and Taranaki, which belonged to the two main gati of the island, served as places for collective turtles ceremonies and renewal of fertility during the rise of the Pleiades Cluster. However, smaller marae also displayed the specific combination of ritual features used for this purpose, including a raganuku, uprights and ovens, although these were apparently located in a single open court (Molle 2015: 32). It 
thus appears that the fundamental ritual of turtle consumption took place at different levels of the Tuamotuan society and on specialised marae where the sizes were adapted to the number of participants. Small family marae can thus be considered as a simplified form of the large gati marae, whose features served the same though less formalised function (Napuka Type 1). Neither Emory (1947) nor Conte (1988) found any of the necessary features for turtles ceremonies on the other Type 2.1 marae of Napuka-Tepoto which display a classic $a h u$. These seem to have had a different function, leading to the idea that specialised ritual activities called for specific features and spatial organisations. In turn, these requirements may be a factor underlying local innovations in marae architecture (Molle 2015: 53). The functions of marae Types 3 and 4 sites, displaying several $a h u$, are not documented ethnographically in the Fangatau Group. In the absence of visible divisions between courts, and lacking stratigraphic evidence in this direction, we can only hypothesise that these large marae could have served for turtle ceremonies as well, with separate $a h u$ facing multiple courts.

Even though ritual consumption of turtles is the most commonly described ceremony in the literature, other religious offerings took place on most marae, in many cases involving certain species of fish (Ottino 1965: 98). Fish were offered on the marae and placed of in front of the upright stones or directly into the small cists in order to ask for future abundance (Garanger and Lavondès 1966: 61, Marchesi and Maric 2005). Like fish, clams constituted a major part of the subsistence on the atolls and were also offered on many marae, slowly forming accumulations of shells which are still visible on some sites (Conte and Dennison 2009: 52, Jacq et al. 2011b). On Ana'a, a traditional classification from Paea-a-Avehe, Stimson's main informant, distinguishes between marae for food consumption, marae for offerings of first fruits, and marae for offerings to the spirits, the latter being small enclosed structures with a wooden post in the middle (Torrente 2012: 246). In the central atolls, accumulations of coral branches, placed in large cists or between slabs, are common features on marae, and called ruahatu, the name of the marine deity to which they were consecrated (Emory 1947: 21). Fishermen and voyagers in canoes used to come to the marae asking for protection while at sea and often dedicated a coral offering to the god. In total, 24 ruahatu have been recorded in the courts of marae of Types 1 (Napuka), 3 and 4.

This brief review of religious traditions in the Tuamotu Islands shows that a number of rituals occurred at different levels of the society, but the majority took place in family contexts on small marae. When the rituals concerned renewal of fertility and abundance, or in more general terms maintaining the balance of natural forces, they happened in both private and collective contexts. However, the current state of ethnographic and archaeological 
information makes the identification of specialised sites very difficult. The only exception is the well-documented case of marae for turtles on Napuka, which featured a combination of diagnostic attributes. Thus it appears that this large variety of rituals may have led to the high degree of marae diversity across the archipelago; in other words, certain combinations of architectural elements, and their organisation, were perhaps related to the specific activities which took place at these sites.

\section{Ancestor Cults and Funerary Practices}

Ethnography has shown that mortuary practices oriented towards ancestor cults were performed on marae (Audran 1918, Caillot 1932, Emory 1947, Montiton 1874). Individuals of high rank usually gained post-mortem access to the status of deified-ancestor (maitu) through a ceremony of apotheosis. Relics from the body, including nails, teeth, locks of hair and sometimes bones and skulls, were removed and kept in sacred containers which were displayed during ceremonies (Emory 1947: 24, Kaeppler 2007, Molle 2015: 54). Moreover, upright coral slabs, either independent or associated with cists, supposedly marked the presence of ancestors and deities in the sacred space during the rites. This function is sometimes reinforced by their anthropomorphic shapes, as documented on Fakahina and Fangatau (Emory 1934: 8, Jacq et al. 2011a, 2011b).

On the other hand, in several cases archaeology has demonstrated burying practices on marae. First described by Emory (1947: 47), the Type 1 marae Te Tahata on Tepoto Atoll was excavated by Conte who discovered 32 individuals buried in front of the cists and uprights in the court (Conte and Calaque 1984, Conte and Dennison 1995, 2009). A similar situation was documented on a small family marae of Napuka where individuals were buried at the foot of the main upright (Conte 2006). These examples prove that, beyond their symbolic representation of, or altar to, the ancestors, upright stones also served as grave markers. On the Rangiroa marae of Huruhuru 'Iore, Garanger uncovered a buried compartment containing the skeleton of a young male (Garanger and Lavondès 1966: 49). On Reao, some burial grounds have been recorded in direct association or in close proximity to Type 2.3 marae (Nitta 1982, Sinoto 1976). These large spaces, delimited by ridges of coral, comprise a series of cists directly dug into the substrate and marked with upright coral slabs at one end. Excavations led by Katayama (in Hatanaka 1982) showed that they contained human remains. From this evidence, a funerary function is hypothesised for sites formed only by series of uprights and cists, as with the Type 1 marae on Marokau, Amanu, Tauere and Hikueru (Conte 1990) or the Type 5 marae (with their compartments) on Ana'a (Maric et al. 2010). 
It seems clear that certain forms of marae allowed for the burying of the dead within a tapu space. Aside from the ritual functions mentioned earlier, this would indicate another aspect of specialised development within religious architecture. ${ }^{2}$ Ancestors played a significant role in the ancient Tuamotuan religion, maybe as important as the deities of the traditional pantheon (Gessler cited by Nolet 2006: 186). It is also known that burying the ancestors symbolically consecrated the residency of a gati on the land (Nolet 2006: 186). The critical concept of ancestor must then be seriously addressed in future functional analyses of marae as it transcends religious, socio-political and funerary contexts.

\section{EXOGENOUS FACTORS AND CULTURAL INFLUENCES}

\section{Rangiroa and a Tahitian Hybridisation Case}

The Mihiroa Group is composed of the seven westernmost Tuamotuan atolls. The distribution analysis of marae types indicates that 36 percent of Type 2.1 and 46 percent of Type 2.2 are found in this area (Molle 2015: 66). Type 2.2 is particularly common on Rangiroa and, as such, was considered as a local type; it consists of marae courts enclosed by double-alignment walls (defined above) and two rows of upright stones on the $a h u$. The historical trajectory of Rangiroa is well documented and shows the developmental process of religious sites here. Traditions recount that first migrants came from Bora Bora in the Leeward Society Islands and settled in the southeastern part of the atoll, forming the gati Oio, which was organised around the original marae of Ra'ipu (Ottino 1967: 25). Indeed, the archaeological survey of these motu showed an early human occupation with open marae made of single ahu platforms, interpreted as an ancient form of ceremonial sites introduced by the first migrants from the Society Islands (Garanger and Lavondès 1966: 45).

Later, the history of the Rangiroa people is closely connected to conflicts that affected the entirety of the Tuamotu Islands from the 17th century, driven by the "imperialistic" attitude of the Parata tribe of Ana'a (Emory and Ottino 1966, Nolet 2006: 500-15, Torrente 2012: 310). The Parata warriors began a series of conquests over the neighbouring islands with the purpose of unifying the population under their control. The raids intensified and focused on the western group of Mihiroa in the second half of the 18th century. On the largest atoll of Rangiroa, the gati faced Parata attacks which led to the abandonment of traditional lands and regrouping around the three major passes, followed by socio-political reorganisation (Ottino 1972). Around 1806, intensification of the conflict ended in the abandoning of the western atolls, with the population finding refuge on the Tahiti Peninsula, in the district of Tautira, where they were granted parts of the land by their allies. In 1821, King Pomare II came to negotiate a peace with Ana'a and put an end to these wars and then, the exiled 
population returned to the island during a "Tahitianisation" phase (Ottino, 1965: 30). Garanger demonstrated that the development of Type 2.2 marae dated from this period (Garanger and Lavondès 1966: 65). Newly founded marae of Type 2.2 showed characteristics from Tahitian sites, including the double-alignment walls enclosure and the double row of three uprights on top and in front of the ahu platforms, some common features in marae of the Tautira District (Garanger 1964). Thus, following the exile period in Tahiti where new marriages and alliances were forged, the people of Rangiroa needed to rethink their own social organisation by founding marae that combined aspects of both cultural groups. Type 2.2 marae were built in a very short and recent period of history and reflect a Tahitian influence on both ceremonial architecture and socio-political structure.

\section{Reao Atoll and the Eastern Connection}

The Reao area shows the largest variability in marae architecture, although the marae here are dominated by the Type 2.3 form which is characterised by long coral ridges along the court sides and $a h u$ made of piled-up coral slabs (Emory 1947). This subclass of marae shows many variations in the sizes and forms of $a h u$ as well. Nitta (1982: 385) proposed a model of development based on the disputable notion of increasing complexity. Following him, the earliest form of marae would have been a series of aligned $a h u$ in an open court, similar to the Types 3 and 4 in Fangatau Atoll. Later, the enclosed marae would have developed, possibly influenced from the West, including Rangiroa and Tongareva, in the northern Cook Islands, where he pinpointed some similarities in the wall construction. He came to conclude that the Reao Type 2.3 was introduced from the Cook Islands through the western part of the Tuamotu Archipelago during migrations that occurred in the 18th century. This model, however, remains uncertain given the very different forms of the northern Cook Islands and western Tuamotu Islands marae. Moreover, his model lacks any chronological or stratigraphic data to support the precedence of one type over another. ${ }^{3}$ Sinoto (1976: 165-71) put more effort towards acquiring dates for settlements and marae development. By synthesising all available data, one could consider an initial settlement in the first half of the second millennium AD, located on the largest lands northwest and southwest of Reao. A cultural influence from the western-central Tuamotu Islands occurred by the 15th century and led to the development of Type 2.1 marae in the main districts of Gake and Tapuarava. On this matter, oral traditions indicate that migrants from Niau and Makemo were allowed to settle on the atoll and build their own marae (Hatanaka 1982: 32). Then, Type 2.3 marae began to develop between the 15 th and 19 th centuries. 
A connection with religious architecture in the Gambier Islands has never been considered in any of these models, although some relevant information was gathered by Emory (1939) and Buck (1938). Following a decade of intensive archaeological research in the Mangareva Group, the possible influences between the two areas must be seriously addressed. Oral traditions recount episodes of migrations from Mangareva towards the eastern Tuamotus, revealing ancient contacts between atolls and high islands (Caillot 1910: 384, 406). On the other hand, archaeology has failed to reconstruct the ancient religious architecture in the Gambier Islands, as the authoritarian missionary occupation, driven by Father Laval, led to a systematic destruction of "pagan" temples, and their quick replacement by new Catholic churches. Thankfully, ritual sites were entirely preserved on the atoll of Temoe, located $50 \mathrm{~km}$ southeast of Mangareva, after it was abandoned in 1838 by order of the missionaries. An intensive archaeological research program has been conducted on Temoe since 2001, leading to an inventory of 500 structures including marae, paved trails, large housing pavements and numerous coral cairns, the majority of which served as burial places (Conte and Weisler 2002, Molle and Murail 2012, Molle et al. 2014). All marae recorded on Temoe Atoll show strong similarities to Type 2.3 Reao sites, such as single and stepped $a h u$ made of piled-up coral slabs and sometimes with side ridges of coral gravel delineating the court space. Although it is too early to assume a clear influence of one region over another, this relationship between the two groups must be taken into account in our developmental perspective of the Reao Type 2.3 marae; they might have originated in a larger cultural context that encompassed the whole of the southeastern part of the archipelago.

$$
* * *
$$

The typology proposed in this study was not intended as a definitive one: further research might reveal other kinds of variation or, alternatively, simplify the types proposed here. However, it is the first attempt since Emory (1947) to synthesise a large dataset at the archipelago scale. This study must be seen as the first stage of a larger holistic approach to ancient Tuamotu Island society for which ritual architecture demonstrates a real potential in tackling questions of cultural change. With the current state of knowledge, one can assume two main drivers of change.

First, endogenous processes most likely include innovations (meaning choices of combinations of features) in response to changing socio-political patterns of organisation, ritual requirements and funerary practices. In short, marae can be seen as physical adaptations to spiritual and socio-political needs through local reinterpretations of an "initial package" (Wallin and 
Martinsson-Wallin 2010). In some cases, this led to highly specialised sites, as demonstrated for instance with the marae tifai in Napuka. Such innovations can occur collectively, privately or at both levels. Also of interest is the development within the Tuamotus of marae genealogies and networks that materialised relationships between groups. However, we still lack archaeological information for considering social organisation and hierarchy as factors of divergence or convergence in marae forms. A monumental reproduction of affiliated marae, however, is possible as other examples are documented in the Society Islands (see Kahn 2010, Wallin and Solsvik 2010), although one might also consider intentional differentiation in the creation of identities (Conte 1997: 167).

Exogenous factors have also been identified in Tuamotus. In the case of Rangiroa's Type 2.2 marae, it is an example of cultures in contact and the process of borrowing which resulted in the development of a hybrid form of marae. In the case of Reao's Type 2.3 marae, it is still too early to evaluate the role of external factors, although recent work in the Gambier region seems to attest to a potential influence from this area but further work is needed.

While this study aims to tackle the issue of marae variability at a broad regional scale, it does not exclude the possibility that multiple and complementary factors may have simultaneously affected marae development on Tuamotu atolls. Perhaps one of the most challenging aspects of this study is that classic archaeological conceptions of so-called marae sites derive from major studies in the Society and Hawaiian Islands, along with Easter Island (Rapa Nui), and these need to be carefully reassessed. Variability in the ritual sites of the Tuamotu Islands (as well as in Marquesas Islands) exemplifies the variable definitions of marae amongst Polynesian communities that are likely to reflect complex cultural phenomena occurring over the long-term. It is now important to explore in more detail the functions of Tuamotuan marae sites through further archaeological investigations, which should be conducted closely with the local communities for whom marae are the most significant remains from their past.

\section{ACKNOWLEDGEMENTS}

I would like to acknowledge Eric Conte for supporting my initial research project on Tuamotu marae which was conducted for my Master's degree. I also would like to acknowledge my colleagues Emilie Nolet, Tamara Maric and Frédérique Torrente for discussions on the topic over the past years. The manuscript beneficiated from detailed comments by two anonymous reviewers and I thank them, as well as Melinda Allen, for their helpful suggestions. 


\section{NOTES}

1 Marae networks are documented in central East Polynesia, the most famous being the one centred on Taputapuatea Marae. It was connected to the 'Oro cult which spread from the Leeward Society Islands to the Windward group, leading to the development of new temple styles (see Eddowes 1991; Kahn 2010; Maric, this issue).

2 Specialised monuments dedicated to mortuary practices are documented in Marquesas Islands (Linton 1925, Molle 2011). On the other hand, discoveries of human burials on Society Island marae remain too few for assigning a specialised funerary function to these sites.

3 Nitta's (1982) model eventually corroborated the traditional information gathered by ethnologist Hatanaka (1982) who directed the research program on Reao.

\section{REFERENCES}

Adams, William Y. and Ernest W. Adams, 1991. Archaeological Typology and Practical Reality - A Dialectical Approach to Artifact Classification and Sorting. Cambridge: Cambridge University Press.

Audran, Hervé, 1918a. Napuka et ses habitants. Bulletin de la Société des Etudes Océaniennes 3: 126-36.

1918b. Traditions of and notes on the Paumotu (or Tuamotu) Islands. Journal of the Polynesian Society 27: 26-35, 90-92, 132-36.

1919. Traditions of and notes on the Paumotu (or Tuamotu) Islands. Journal of the Polynesian Society 28: 31-38, 161-67, 232-39.

-1927a. Fakahina. Bulletin de la Société des Etudes Océaniennes 19: 227-35. 1927b. Fakahina. Bulletin de la Société des Etudes Océaniennes 20: 251-59.

Benzécri, Jean-Pierre, 1973. L'analyse des données. Tome 2: l'analyse des correspondances. Paris: Editions Dunot.

Buck, Peter, 1938. Ethnology of Mangareva. Bernice P. Bishop Museum Bulletin 157. Honolulu.

Caillot, Eugène, 1910. Histoire de la Polynésie orientale. Paris: Librairie Ernest Leroux.

-1932. Histoire des religions de l'archipel Paumotu (avec des tableaux de la société indigène et des traditions anciennes). Paris: Librairie Ernest Leroux.

Chazine, Jean-Michel, 1977. Prospections archéologiques à Takapoto. Journal de la Société des Océanistes 33: 191-208.

1982. Preliminary report on archaeological research. In S. Hatanaka and N. Shibata (eds), Reao Report. A Study of the Polynesian Migration to the Eastern Tuamotus. Kanazawa: University of Kanazawa, pp. 267-348.

-1984. Datations au C14 à Reao. Bulletin de la Société des Etudes Océaniennes 228: 1654-59.

2003. Recherches archéologiques à Makemo, Tuamotu. Dossier d'Archéologie Polynésienne 2: 117-36.

-2005. Complément d'enquête archéologique aux Tuamotu de l'Est (atoll de Tatakoto). Dossier d'Archéologie Polynésienne 4: 191-200.

Cochrane, Ethan E., 1998. Recent research and future advances in the analysis of Polynesian ceremonial architecture: A review essay. Asian Perspectives 37 (2): 279-300. 
2015. Phylogenetic analysis of Polynesian ritual architecture suggests extensive cultural sharing and innovation. Journal of the Polynesian Society 124 (1): 7-46.

Conte, Eric, 1988. L'Exploitation Traditionnelle des Ressources Marines à Napuka (Tuamotu - Polynésie Française). Unpublished PhD dissertation, University Paris I Panthéon-Sorbonne, 3 volumes.

1990. Archéologie des Tuamotu: Prospection de dix atolls au centre de l'archipel. Punaauia: Département Archéologie du CPSH.

— 1997. La différenciation culturelle en Polynésie orientale. Propositions pour une interprétation alternative. Journal de la Société des Océanistes 105 (2): 157-71. 2000. L'archéologie en Polynésie française. Esquisse d'un bilan critique. Papeete: Editions Au Vent des Iles.

2006. Travaux archéologiques à Napuka et Tepoto (archipel des Tuamotu, Polynésie Française). Punaauia: Rapport Université de la Polynésie Française.

Conte, Eric and Isabelle Calaque, 1984. Notes sur les investigations archéologiques menées à Tepoto. Bulletin de la Société des Etudes Océaniennes 228: 1667-69.

Conte, Eric and Kenneth Dennison, 1995. An anthropological study of the burial in marae Te Tahata, Tepoto. Journal of the Polynesian Society 104 (4): 397-427.

2009. Te Tahata, étude d'un marae de Tepoto (Nord), Archipel des Tuamotu, Polynésie française. Les Cahiers du CIRAP, Vol. 1. Punaauia.

Conte, Eric and Marshall Weisler, 2002. Recherches archéologiques sur l'atoll de Temoe (Archipel des Gambiers). Punaauia: Rapport Service de la Culture et du Patrimoine.

Dauphin, C., 2005. Prospection et inventaire archéologique de l'atoll de Mataiva. Dossier d'Archéologie Polynésienne 4: 185-90.

Dunnell, Robert C., 1971. Systematics in Prehistory. New York: Free Press.

Eddowes, Mark, 1991. Ethnohistorical Perspective on the Marae of the Society Islands: The Sociology of Use. Unpublished M A thesis, Anthropology, University of Auckland.

Emory, Kenneth P., 1932. The Tuamotu Survey. In H. E. Gregory (ed.), Report of the Director for 1931. Bulletin 94. Honolulu: Bernice P. Bishop Museum, pp. 40-50. 1933. Stone Remains in Society Islands. Bernice P. Bishop Museum Bulletin 116. Honolulu.

—1934. Tuamotuan Stone Structures. Bernice P. Bishop Museum Bulletin 118. Honolulu.

- 1939. Archaeology of Mangareva and Neighboring Atolls. Bernice P. Bishop Museum Bulletin 163. Honolulu.

1947. Tuamotuan Religious Structures and Ceremonies. Bernice P. Bishop Museum Bulletin 191. Honolulu.

1970. A re-examination of East Polynesian marae: Many marae later. In Roger Green and Marion Kelly (eds), Studies in Oceanic Culture History 1. Pacific Anthropological Records 12. Honolulu: Bernice P. Bishop Museum, pp. 73-92. 1975. Material Culture of the Tuamotu Archipelago. Pacific Anthropological Records 22. Honolulu: Bernice P. Bishop Museum.

Emory, Kenneth P. and Paul Ottino, 1966. Ana'a, histoire ancienne d'un atoll polynésien. Journal de la Société des Océanistes 23: 29-57.

Garanger, José, 1964. Recherches archéologiques dans le district de Tautira, Tahiti. Journal de la Société des Océanistes 20: 5-21. 
Garanger, José and Anne Lavondès, 1966. Recherches archéologiques à Rangiroa. Journal de la Société des Océanistes 22: 25-66.

Gérard, Bertrand, 1974. Origine traditionnelle et rôle social des marae aux îles de la Société. Cahiers ORSTOM, Série Sciences Humaines 9 (3-4): 211-26.

_ 1978a. L'époque des marae aux îles de la Société. Unpublished PhD dissertation, University Paris X Nanterre.

-1978b. Le marae: Description morphologique. Cahiers ORSTOM, Série Sciences Humaines 15 (4): 407-48.

Hatanaka, Sachiko, 1982. Ethnological research. In S. Hatanaka and N. Shibata (eds), Reao Report: A Study of the Polynesian Migration to the Eastern Tuamotus. Kanazawa: University of Kanazawa, pp.18-76.

Henry, Teuira, 2000 [1928]. Tahiti aux temps anciens. Publication de la Société des Océanistes 1. Paris.

Jacq, Frédéric, Jean-François Butaud and Tamara Maric, 2011a. Diagnostic environnemental et socio-économique du Plan Général d'Aménagement (PGA) de la commune de Fangatau, atoll de Fangatau, Tuamotu. Rapport pour le Service de l'Urbanisme. Papeete.

Jacq, Frédéric, Jean-François Butaud and Guillaume Molle, 2011b. Diagnostic environnemental et socio-économique du Plan Général d'Aménagement (PGA) de la commune de Fangatau, atoll de Fakahina, Tuamotu. Rapport pour le Service de l'Urbanisme. Papeete.

Kaeppler, Adrienne, 2007. Containers of divinity. Journal of the Polynesian Society 116 (2): $97-130$.

Kahn, Jennifer G., 2010. A spatio-temporal analysis of 'Oro cult marae in the 'Opunohu valley, Mo'orea, Society Islands. Archaeology in Oceania 45: 103-10.

Kahn, Jennifer G. and Patrick V. Kirch, 2014. Monumentality and Ritual Materialization in the Society Islands: The Archaeology of a Major Ceremonial Complex in the 'Opunohu Valley, Mo'orea. Bernice P. Bishop Museum Bulletin in Anthropology 13. Honolulu: Bernice P. Bishop Museum Press.

Kirch, Patrick V., 1984. The Evolution of Polynesian Chiefdoms. Cambridge: Cambridge University Press.

Kirch, Patrick V. and Roger C. Green, 1987. History, phylogeny and evolution in Polynesia. Current Anthropology 28: 431-56.

-2001. Hawaiki, Ancestral Polynesia. An Essay in Historical Anthropology. Cambridge: Cambridge University Press.

Linton, Ralph, 1925. Archaeology of the Marquesas Islands. Bernice P. Bishop Museum Bulletin 23. Honolulu.

Marchesi, Henri and Tamara Maric, 2005. Le marae Tainoka de Fakarava, un nouveau type de marae aux Tuamotu de l'Ouest. Dossier d'Archéologie Polynésienne 4: 152-63.

Maric, Tamara, 2010. Archéologie et traditions orales des atolls de Nukutavake, Vaira'atea et Pinaki (archipel des Tuamotu, Polynésie Française). Rapport du Service de la Culture et du Patrimoine. Punaauia.

Maric, Tamara, Frédéric Torrente and Jean-François Butaud, 2010. Prospection archéologiques de l'atoll de Anaa, archipel des Tuamotu (juillet-août 2009). Rapport préliminaire. Punaauia.

Molle, Guillaume, 2011. Ua Huka, une île dans l'Histoire. Histoire pré- et posteuropéenne d'une société marquisienne. Unpublished PhD Dissertation, University of French Polynesia. 
2015. Ancêtres-dieux et temples de corail. Approche ethnoarchéologique du complexe marae aux Tuamotu, Polynésie française. Les Cahiers du CIRAP, Vol. 3. Punaauia.

Molle, Guillaume and Pascal Murail, 2012. Recherches archéologiques et anthropologiques sur l'atoll de Temoe (Archipel des Gambier), campagne 2010. Rapport du CIRAP. Punaauia.

Molle, Guillaume, Pascal Murail and Aymeric Hermann, 2014. Recherches archéologiques et anthropologiques sur l'atoll de Temoe (Archipel des Gambier), campagne 2013. Rapport du CIRAP. Punaauia.

Montiton, Albert, 1874. Les missions catholiques, 6: 339, 342-44, 354-56, 362-67, 378-79, 491-92, 498-99, 502-4.

Nitta, Eiji, 1982. Archaeological research. In S. Hatanaka and N. Shibata (eds), Reao Report. A Study of the Polynesian Migration to the Eastern Tuamotus. Kanazawa: University of Kanazawa, pp. 348-430.

Niva, Paul, 2007. Inventaire archéologique à Niau. Unpublished report. Punaauia.

Niva, Paul and Eli Poroi, 2005. Inventaire du patrimoine de l'île de Makatea. Rapport de l'association Terau ati ati. Papeete.

Nolet, Emilie, 2000. La tortue et les cultures du Pacifique. Unpublished Master's dissertation, University Paris I Panthéon-Sorbonne. 2006. L'organisation socio-politique des Tuamotu durant la dernière période pré-européenn: éléments d'approche critique et comparative. Unpublished $\mathrm{PhD}$ thesis, Université Paris I Panthéon-Sorbonne.

2007. Figures du pouvoir dans l'archipel des Tuamotu (Polynésie française: Ce que c'est que d'être chef. Journal de la Société des Océanistes 124: 119-40.

-2014. Le cadet à la peau rouge. Pouvoir et parenté dans l'archipel des Tuamotu. Paris: Editions du CTHS.

Orliac, Catherine, 2000. Fare et Habitat à Tahiti. Marseille: Editions Parenthèses.

Ottino, Paul, 1965. Ethnohistoire de Rangiroa (archipel des Tuamotu). Papeete: ORSTOM.

-1967. Early 'ati of the Western Tuamotu. In G.A. Highland. R.W. Force, A. Howard, M. Kelly and Y.H. Sinoto (eds), Polynesian Culture History, Essays in Honor of Kenneth P. Emory. Bernice P. Bishop Museum Special Publication 56. Honolulu: Bernice P. Bishop Museum Press, pp. 451-81.

_ 1972. Rangiroa: Parenté étendue, résidence et terres dans un Atoll Polynésien. Paris: Editions Cujas.

Seurat, Léon, 1905. Les marae des îles orientales des Tuamotu. L'Anthropologie 16: 475-84.

Sinoto, Yosihiko, 1976. Preliminary report of archaeological survey on Reao Atoll. In S. Hatanaka and N. Shibata (eds), Reao Report. A Study of the Polynesian Migration to the Eastern Tuamotus. Kanazawa: University of Kanazawa, pp. 102-79.

Sodter, François, 1984. Notes sur quelques sites archéologiques de Mataiva. Archives des Sciences Humaine 84-11. Papeete: ORSTOM.

Souhaile, Pierre, 1972. Les marae de Tureia. Bulletin de la Société des Etudes Océaniennes 179: 180-91.

Stimson, Frank J., 1933a. Tuamotuan Religion. Bernice P. Bishop Museum Bulletin 103. Honolulu. 1933b. The Cult of Kiho Tumu. Bernice P. Bishop Museum Bulletin 111. Honolulu. 1937. Tuamotuan Legends (Island of Anaa). Bernice P. Bishop Museum Bulletin 148. Honolulu. 
Stimson, Frank J. and Donald S. Marshall, 1964. A Dictionary of Some Tuamotuan Dialects of the Polynesian Language. Salem: Peabody Museum of Salem, Massachusetts and Het Koninklijk Institute Voor Tall.

Torrente, Frédéric, 2012. Buveurs de mers, mangeurs de terres. Histoire des guerriers d'Anaa, atoll des Tuamotu. Papeete: Te pito o te fenua.

Vérin, Pierre, 1964. Ra'iupu marae of Makatea, Tuamotu Islands. Asian Perspectives 7: 212-15.

Vigneron, Emmanuel, 1984. L'atoll de Tikehau. Recherches sur 1'histoire et l'archéologie. Rapport de mission no. 84-02. ORSTOM, Papeete.

Wallin, Paul, 1993. Ceremonial Stone Structures: Archaeology and Ethnohistory of a Marae Complex in the Society Islands. Uppsala: AUN.

Wallin, Paul and Helene Martinsson-Wallin, 2010. Monumental structures and the Spirit of chiefly actions. Time and Mind. The Journal of Archaeology, Consciousness and Culture 4 (1): 43-58.

Wallin, Paul and Reidar Solsvik, 2010. Archaeological Investigations in Huahine, in Society Islands, French Polynesia. Report and Discussions. BAR International Series 2091. Oxford: Archaeopress.

\begin{abstract}
The archaeology of the Tuamotu Islands in central East Polynesia mainly derives from studies of ritual architecture. Since the pioneering works of Kenneth P. Emory in the 1930s, around 650 marae have been recorded in the archipelago. Surface inventories show that the basic architectural features of marae were organised in a diversity of patterns, which reflect the complex histories of local communities. To investigate the variability of these monuments, a taxonomic classification of these marae sites was developed, the first geographically extensive analysis of its kind. Relying on archaeological and ethnohistorical evidence, in addition to oral traditions, an attempt is made here to explain the development of these sites, considering endogenous sociopolitical processes, ritual innovations and external influences.
\end{abstract}

Keywords: Polynesia, Tuamotu Islands, marae, typology, indigenous rituals, religious architecture

\title{
CITATION AND AUTHOR CONTACT DETAILS
}

Molle, ${ }^{1}$ Guillaume, 2016. Exploring religious practices on Polynesian atolls: A comprehensive architectural approach towards the marae complex in the Tuamotu Islands. Journal of the Polynesian Society 125 (3): 263-288; DOI: http//dx.doi. org/10.15286/jps.125.3.263-288

${ }^{1}$ Correspondence: School of Archaeology and Anthropology, The Australian National University, A.D. Hope Building, 14 Ellery Crescent, Canberra, ACT 2601, Australia. Email: Guillaume.Molle@anu.edu.au 